\title{
IAMJ
}

INTERNATIONAL

AYURVEDIC

MEDICAL JOURNAL

\section{EVALUATION OF SMRUTIRHASA (MEMORY LOSS) IN OLD AGED INDIVIDUALS AND EFFECT OF BRAMHI SIDDHA GHRITA ON SHORT TERM MEMORY LOSS}

\author{
Bhargav G. Tappe', Sampada S Sant ${ }^{2}$, Abhijeet Gawai ${ }^{3}$ \\ ${ }^{1}$ Assistant Professor, Department of Kriya Sharir, Dr Rajendra Gode Ayurved College, Hospital \& Research \\ Center, University Mardi Road, Amravati, Maharashtra, India \\ ${ }^{2}$ Professor \& H.O.D, Department of Kriya Sharir, Govt. Ayurved College Nanded, Maharashtra, India \\ ${ }^{3}$ Assistant Professor, Department of Agadtantra, Dr Rajendra Gode Ayurved College, Hospital \& Research \\ Center, University Mardi Road, Amravati, Maharashtra, Maharashtra, India
}

Corresponding Author: tappe.bhargav@gmail.com

\section{https://doi.org/ $10.46607 /$ iamj0808082020}

(Published online: August 2020)

Open Access

(C) International Ayurvedic Medical Journal, India 2020

Article Received: 17/07/2020 - Peer Reviewed: 04/08/2020 - Accepted for Publication: 14/08/2020

\section{Check for updates}

\begin{abstract}
Memory disorders are increasing at fast rate in modern society. Neurological disorders like Alzheimer's disease, Parkinson's disease also affect memory. Due to ageing process a greater number of old aged individuals are facing problem of memory loss i.e. Smrutirhasa (Memory Loss) which leads to their behavioral change and cognitive impairment ultimately leads to land them in senile dementia. In first part of study 100 old aged individuals were randomly selected for evaluation of Smrutirhasa in second part of study, effect of Bramhi Siddha Ghrita was observed for period of 2 months after obtaining Short term memory status of individuals having Smrutirahsa. According to statistical analysis $66 \%$ of individuals above 60 years were having Smrutirhasa and treatment by Bramhi Siddha Ghrita shows significant result over short term memory loss in them.
\end{abstract}

Keywords: Smrutirahasa, Bramhi Siddha Ghrita, short term memory loss. 


\section{INTRODUCTION}

According to Acharya Charaka deterioration of Smruti (Memory) leads to Pradhnyaparadha (Volitional transgression) which is one of the main reasons to get diseased ${ }^{1}$ and also above the age of 60 year there will be deterioration of many functions and Smruti is one of them ${ }^{2}$. In Ayurveda classics, different aspects of Smruti are described in Prakruti Pariksha (Examination of body type). We cannot change Prakruti (Body type) of a person. But if one knows capacity \& accuracy of his memory, it can be improved by using various memory aids.

Now a day, due to changed lifestyle $\&$ increased stressful life and ageing process a greater number of old aged individuals are facing problem related to memory. Memory disorders are also increasing at fast rate. Neurological disorders like Alzheimer's disease, Parkinson's disease also affects memory. Process of ageing causes Smrutirhasa in old age people which leads to behavioral change and cognitive impairment and senile dementia in them. Senile dementia affects life of individual along with society. To live the healthy life, person must be physically and mentally fit. For keeping physical fitness there are description of many Rasayana (rejuvenating therapy), Vyayam (Exercise) and Ahara (dietary pattern). Knowing the importance of Smruti, Acharya Charaka has described the Rasayana like Endra Rasayana ${ }^{3}$ which includes the memory enhancing drug Bramhi ${ }^{4}$. Ghrita (Ghee) is also described as Vayasthapanam Param ${ }^{5}$ i.e. an age stabilizer agent and can be taken by the old aged individuals who wants to have good Smruti $^{6}$.

Modern science has limitations to improve Smruti in old aged persons as it is due to ageing process. So the present study entitled "To evaluate Smrutirhasa in old aged individuals and effect of Bramhi Siddha Ghrita on short term memory loss" is a humble attempt to study the Smrutirhasa in old aged individuals and to study the effect of Bramhi Siddha Ghrita over short term memory loss. In first part of study 100 old aged individuals were randomly selected for evaluation of Smrutirhasa (Memory Loss). In second part of study after obtaining Short term memory status of individuals having Smrutirahsa, effect of Bramhi Siddha Ghri- ta was observed for period of 2 months. According to statistical analysis $66 \%$ of individuals above 60 years were having Smrutirhasa and treatment by Bramhi Siddha Ghrita shows significant result over short term memory loss in them.

\section{Objectives}

1. Evaluation of Smrutirhasa in old aged individuals.

2. To study the effect of Bramhi Siddha Ghrita in Smrutirhasa (short term memory loss) due to ageing process in old aged individuals.

\section{Material and Methods}

Ethical clearance-Institutional Ethics Committee Approval and Regulatory Compliance

Before the initiation of the study, the study protocol and related documents were reviewed and approved by Institutional Ethics Committee at Govt. Ayurved College, Vazirabad, Nanded. The study was conducted in accordance with Schedule Y of Drugs and Cosmetics act, India, amended in 2005. IEC Clearance No -GAC/IEC-NO/168/2014, Date 10/122014.

\section{1) Selection of the volunteers: -}

Study was conducted in two parts.

In first part, following Criteria was applied to evaluate Smrutirhasa (Memory Loss) in old aged individual.

\section{A) Inclusive criteria: -}

1. 100 volunteers had selected.

2. Sex: Irrespective of male female

3. Education: Above $10^{\text {th }}$ standard

4. Age cohort : 60- 80 yrs.

In the second part, effect of Bramhi Siddha Ghrita on short term memory was studied. For this study following inclusive criteria was applied.

1. Individuals having score less than 7 obtained by applying questionnaire (A) had selected.

\section{B) Exclusive Criteria:}

1. Persons having senile dementia.

2. Persons having DM, cerebrovascular diseases.

3. Persons having psychiatric disorders i.e. schizophrenia, depression, generalized anxiety disease.

4. Persons having Alzheimer's disease.

5. Persons having history of brain trauma i.e. stroke, accident, etc. 
6. Persons having sensory organ impairment i.e. blindness, deafness, etc.

7. Persons having neurological disorders. i.e. parkinsonism etc.

8. Persons having blood pressure $>160 / 90$, serum total cholesterol level $>200$, serum triglyceride level $>15$.

\section{Method of preparation of Bramhi Siddha Ghrita}

Bramhi was taken in Bharad (crude) form and was soaked overnight in 16 liters of water (1:8). 1/4 i.e. 4- liter Kwath (decoction) was prepared ${ }^{7}$. Filtered Kwath was mixed with 1 liter of cow Ghee (Ghrita) and 250 gm of Bramhi Kalka (paste). The mixture was boiled on low heat till all water get evaporated and only Ghee (Ghrita) remained and all Snehasidhi Lakshana ${ }^{8}$ were obtained.

Standardized Bramhi Siddha Ghrita has standardization values as

\begin{tabular}{|l|l|c|}
\hline 1 & Refractive index & 1.4560 \\
\hline 2. & Acid value of & $2.57 \mathrm{ml} \mathrm{of} \mathrm{KOH}$ \\
\hline
\end{tabular}

\section{Design of Study}

1. 100 volunteers having age between $60-80$ years were randomly selected.

2. Memory score was obtained by applying Questionnaire (A) and evaluation of Smrutirhasa was done.

3. A group of 30 volunteers having score less than or equal to 7 obtained by applying Questionnaire (A) were selected.

4. Questionnaire (B) was applied and their shortterm memory score was obtained from the above group. In This Questionnaire picture was shown for 15- 20 minutes and Questions based over that picture were asked and score was obtained.

5. Bhramhi Siddha Ghrita was given to the above group of volunteers for a period of 60 days with a dose of $20 \mathrm{ml}$ at morning and evening after meal and volunteers were followed up on $0^{\text {th }}, 30^{\text {th }}, 60$ day.

6. At $60^{\text {th }}$ day again Questionnaire (B) was applied and short-term memory score was obtained after the treatment by Bramhi Siddha Ghrita.

7. Establishment of short-term memory score obtained by Questionnaire (B) before and after the treatment by Bramhi Siddha Ghrita for evaluation of result was done.

\section{Parameters}

\section{Questionnaire (A) For Smrutirhasa examina- tion.}

It contains 21 questions based on the Lakshanas of memory in different Prakruti. Each yes answer has given one score and no answers has given zero score. For convenience of subjects and accuracy of result questions were translated in their regional language. Scoring Pattern was for Pravara Smruti (good memory) 15- 21yes answers, Madhyama Smruti (average memory) 8-14 yes answers and Avara Smruti (low memory) less than or equal to 7 yes answers

\section{Questionnaire (B) Standardized short term memory scale}

It was named as Material for Accuracy of Testimony, used to find the significance of treatment on short term memory loss with Bramhi Siddha Ghrita. It contains one picture showing an incidence of accident in city and 34 questions based on that picture. For convenience of subjects and accuracy of result, picture was labeled in regional language and questions were also translated in regional language of subject.

\section{Observation and Results}

Table 1: Smruti wise distribution of subject.

\begin{tabular}{|l|l|l|l|l|l|}
\hline Smruti & Pravara & Madhyam & Avara & Total \\
\hline No of subjects & $12(12 \%)$ & $22(22 \%)$ & $66 \quad(66 \%)$ & $100(100 \%)$ \\
\hline
\end{tabular}


Table 2: Age wise distribution of 100 subjects according to Smruti

\begin{tabular}{|l|l|l|l|l|l|}
\hline Sr. no. & Age groups & Smruti & Total \\
\cline { 3 - 5 } & & Pravara & Madhyam & Avara & \\
\hline 1. & $60-65$ & $5(13.15 \%)$ & $9(23.68 \%)$ & $24(63.15 \%)$ & $\mathbf{3 8 ( 1 0 0 \% )}$ \\
\hline 2. & $66-70$ & $4(9.30 \%)$ & $8(18.60 \%)$ & $31(72.09 \%)$ & $\mathbf{4 3 ( 1 0 0 \% )}$ \\
\hline 3. & $71-75$ & $2(18.18 \%)$ & $4(36.36 \%)$ & $5(45.45 \%)$ & $\mathbf{1 1 ( 1 0 0 \% )}$ \\
\hline 4. & $76-80$ & $1(12.5 \%)$ & $1(12.5 \%)$ & $6(75 \%)$ & $\mathbf{8}(\mathbf{1 0 0})$ \\
\hline & Total & $\mathbf{1 2}(\mathbf{1 2 \%})$ & $\mathbf{2 2}(\mathbf{2 2 \%})$ & $\mathbf{6 6}(\mathbf{6 6 \%})$ & $\mathbf{1 0 0 ( 1 0 0 \% )}$ \\
\hline
\end{tabular}

Table 3: Prakruti wise distribution of 100 subjects according to Smruti

\begin{tabular}{|l|l|l|l|l|l|}
\hline Sr. no & Prakruti & \multicolumn{2}{|l|}{ Smruti } & Total \\
\hline Pravara & Madham & Avara & \\
\hline 1$]$ & Vata Pradhan & $1(1.72 \%)$ & $4(6.89 \%)$ & $53(91.37 \%)$ & $\mathbf{5 8}$ \\
\hline 2$]$ & Pitta Pradhan & $4(20 \%)$ & $7(35 \%)$ & $9(45 \%)$ & $\mathbf{2 0}$ \\
\hline 3$]$ & Kapha Pradhan & $7(31.81 \%)$ & $11(50 \%)$ & $4(12.5 \%)$ & $\mathbf{2 2}$ \\
\hline Total & & & & $\mathbf{1 0 0}$ \\
\hline
\end{tabular}

Table 4: Dhatu Sarata wise distribution of 100 Subjects according to Smruti.

\begin{tabular}{|l|l|l|l|l|l|}
\hline Sr. no & Sarata & Smruti & Total \\
\cline { 3 - 5 } & & Pravara & Madhyam & Avara & \\
\hline 1$]$ & Uttam & $3(60 \%)$ & $1(20 \%)$ & $1(20 \%)$ & $\mathbf{5}(\mathbf{1 0 0 \% )}$ \\
\hline 2$]$ & Madhyam & $4(11.76 \%)$ & $9(26.47 \%)$ & $21(61.76 \%)$ & $\mathbf{3 4}(\mathbf{1 0 0 \% )}$ \\
\hline 3$]$ & Hina & $5(8.19 \%)$ & $12(19.67 \%)$ & $44(72.13 \%)$ & $\mathbf{6 1}(\mathbf{1 0 0 \% )}$ \\
\hline Total & & & & $\mathbf{1 0 0}$ \\
\hline
\end{tabular}

(2) Effect of treatment on Short term memory score

Table 5: Showing the effect of Bramhi Siddha Ghrita on 'short term memory loss.'

\begin{tabular}{|l|l|l|l|l|l|l|}
\hline & Mean & S.D & S.E & "t" calculated & P & t- table \\
\hline BT & 6.080 & 1.816 & 0.2569 & & & \\
\hline AT & 6.400 & 1.773 & 0.2507 & 2.682 & $<0.05$ & 2.011 \\
\hline
\end{tabular}

\section{DISCUSSION}

Age: Above the of 60 years i.e. in Jirna Vayaavastha (old age) there is deterioration of memory along with Dhatubala, Dhatuguna, Indriyabala, Sharirabala and many more 9 . Also, there is predominance of Vata Dosha in Jirna Vayaavastha ${ }^{10}$ which is responsible for Smrutirhasa above 60 years.

According to modern science working memory, episodic memory and short-term declines as age progresses. Due to ageing there is degradation of white matter and also there is decline in the interconnection networks spanning frontal, temporal and parietal lobe which enables different aspects of memory.
Prakruti: According to Acharya Charaka Vata Prakruti Laskan is ShrutagrahinyoAlpasmrutayashcha $^{l 1}$ (the one who can get things quickly but forgets easily) and according to Acharya Vaghbata it is Shighraarambhakshobhgrahanvismaran $^{12}$. So, it can be concluded that Vata Pradhan individual will grasp quickly and forgets quickly and they are having low memory (Alpasmrutayah) as compared other individual. They mentioned that Pita Prakruti have Madhyamdhyanvidhnyan ${ }^{13}$ i.e. they have Average memory. According to them Kapha Prakruti individual are Smrutiman ${ }^{14}$ i.e. they have a good memory. 
Dhatu Sarata: Dhatu Sarata Parikshan is a method of examination to assess Dhatu quality wise \& quantitywise ${ }^{15}$. Uttam Dhatusarata indicates that, qualitatively, quantitatively and functionally Dhatu is effective and Hinasarata indicates that Dhatu is less effective than its normal stage. Hinasara Dhatu causes vitiation of Vata Dosha which leads to the reduction of Smruti in Avara Dhatu Sara Purusha as compared to Uttam and Madhyam Dhatusara Purusha.

Discussion on Evaluation of Smrutirhasa: Above the of 60 years i.e. in Jirna Vayaavastha (old age) there is deterioration of memory along with Dhatubala, Dhatuguna, Indriyabala, Sharirabala and many more due to predominance of Vata Dosha. Chala Guna of Vatadosha which is opposite to Sthira Guna affects the Dharan function i.e. holding and recalling property of brain. According to Acharya Vaghbhata Vatadoshavrudhhi causes Majja Dhatu Shoshana ${ }^{16}$ (degeneration of nerve fibers) and Indriyabransh (impairment of sense organ), which ultimately leads to Smrutirhasa in old aged individuals.

Discussion on Result: Out of 100 Subjects 66\% subjects were having Avara Smruti, 22\% subjects were having Madhyam Smruti, 12\% subjects were having Pravara Smruti. So, majority of subjects were having Avara Smruti. So, there is Smrutirhasa in individuals above the age of 60 which is Jirna Vayaavastha. In this stage there is predominance of Vata Dosha along with the age-related degeneration of all Dhatu with Majja Dhatu (Nervous tissue). Degeneration of Majja Dhatu can lead to Indriya Bala Kshaya (impairment in the function of nervous tissue) which ultimately responsible for the Smrutirhasa in Jirna Vayaavastha i.e. in old age.

\section{Effect of Bramhi Siddha Ghrita on short term memory loss}

In the second part effect of Bramhi Siddha Ghrita on short term memory loss was studied. For that out of 66 subject 50 subject having Avara Smruti were selected. 16 subjects were eliminated from the study as they failed to follow the protocols of the study. As mean value of calculated " $\mathrm{t}$ " is greater than the table value Bramhi Siddha Ghrita significantly improve the shortterm memory score.
Probable mode of action of drug: Bramhi Siddha Ghrita reaches up to the minute channels buy Sukshmaguna of Sneha and nourishes the tissue cells. Bramhi Siddha Ghrita contains Bramhi and Cow ghee (Ghrita). Bramhi has Tridoshaghna property. ChalaRuksha Guna of Vatadosha and Ushna-Tikshna Guna of Pitta Dosha are responsible for the Smrutirhasa. Bramhi cause Vata Dosha Shamana by its Madhura Rasa and Pitta Dosha Shaman by its Kashaya-TiktaMadhura rasa and Shitavirya. Bramhi nourishes the brain tissue and responsible for the regulation of $M a j-$ javaha Srotas function. Bhramhi has Rasayana property by its Madhurguna and Vipaka.

According to Charaka old age individual who wants to improve memory should use Ghrita as a Snehapana. So Bramhi Siddha Ghrita was prepared and used in the treatment. It is given in $20 \mathrm{ml}$ dose BD after meal i.e. in Vyanodan Bheshajya Kale. Maintenance of Smruti is function of Udanvayu and Sadhaka Pitta. The Bramhi Siddha Ghrita which was used at Vyanodan kale in the current study responsible for Shama$n a$ and regulation of Smaranam function of Udanvayu. Bramhi Siddha Ghrita causes Shaman of the Sadhaka Pitta who controls the function of Buddhi and Smruti. According to modern science Bramhi has anti-anxiety, anti-depressant, sedative, smooth muscle relaxant, anti-spasmodic and memory enhancing property ${ }^{17}$. Bramhi increases the retention of information; improve the IQ levels, general debility, behavioral patterns, mental concentration and mental clarity and memory recall due to presence of Becoside A and Becoside B. Bramhi increase the level of serotonin a brain chemical known to improve relaxation to improve memory function by boosting brain function and by reducing the anxiety. It increases the sense of calm and peace in the users. By increasing the protein synthesis, it increases the activity of brain and improves the mental alertness and enhances the learning capacity of brain. It neutralizes all the free radicals inside the brain, the lining of brain cells are also get protected and its action prevents long term damage to nerve tissue making up brain. Bacoside A1-A3, Bacopasaponins A-G(4-7), Bacopasids $\mathrm{I}-\mathrm{V}(8-9)$ in Bramhi modulates various neurotransmitters such as 
acetylcholine, serotonin (5-hydroxytryptamine) i.e. 5HT, GABA (gamma amino butyric acid), glutamate (glu) and dopamine at the different brain regions to enhance the memory. Bacoside influences the seratonergic system due to interaction with the cholinergic system. The improvement observed into the hippocampus dependent learning is due the combined effect of serotonin and cholinergic system. This is conformed to the finding the multiple neurotransmitters which are involved into the learning and memory process.

\section{CONCLUSION}

From the current study it is concluded that there is presence of Smrutirahasa (Memory Loss) in old aged individuals which was mentioned in literature. Age, Prakruti, Dhatu Sarata (quality of Dhatu) are the factors affecting the memory status of old age individual. Vataprakaruti Purusha, Avara Dhatu Sarata and agerelated degeneration of Majja Dhatu may lead to Smrutirahasa (Memory Loss) in old age individuals. Bramhi Siddha Ghrita causes Shamana of Vata Dosha, by its Madhura Rasa, Snigdha, Guruguna. It improves the regulatory activity of Sadhak Pitta and Udan Vayu which controls memory function. Bramhi Siddha Ghrita has anti-anxiety, anti-depressant, sedative, smooth muscle relaxant, anti-spasmodic and memory enhancing property which increases the retention of information, improve the IQ levels, general debility, behavioral patterns, mental concentration and mental clarity and memory recall due to presence of Becoside $\mathrm{A}$ and Becoside $\mathrm{B}$ which modulates various neurotransmitters such as acetylcholine, serotonin(5hydroxytryptamine) i.e. 5HT, GABA (gammaamino butyric acid), glutamate (glu) and dopamine at the different brain regions to enhance the memory.

\section{REFERENCES}

1. Vd Harishchandra Singh Kushvaha, Charak Samhita, reprints 2016, Chaukhamba Orientaliya Varanasi, Page No.736

2. Vd Harishchandra Singh Kushvaha, Charak Samhita, reprints 2016, Chaukhamba Orientaliya Varanasi, Page No.696

3. Vd Harishchandra Singh Kushvaha, Charak Samhita, reprints 2016, Chaukhamba Orientaliya Varanasi, Page No.29
4. Bhishagratna shree Bramhashankar Mishra, Bhavprakash Niganthu, Edition 12, 2016, Chaukhamba Sanskrit Prakashan, Varanasi, Page no. 623.

5. Dr. Bramhananda Tripathi, Ashtanghrudayam, reprints 2014, Chaukhamba Sanskrit Prakashan, Varanasi, Page no. 73

6. Dr. Bramhananda Tripathi, Ashtanghrudayam, reprints 2014, Chaukhamba Sanskrit Prakashan, Varanasi, Page no. 73 .

7. Acharya P Radhakrushna Parashar, Sharangdhar Samhita, reprint 2012, Baidyanath Ayurved Bhavan, Page No.183.

8. Acharya P Radhakrushna Parashar, Sharangdhar Samhita, reprint 2012, Baidyanath Ayurved Bhavan, Page No.319.

9. Vd Harishchandra Singh Kushvaha, Charak Samhita, reprints 2016, Chaukhamba Orientaliya Varanasi, Page No.696.

10. Vd Harishchandra Singh Kushvaha, Charak Samhita, reprints 2016, Chaukhamba Orientaliya Varanasi, Page No.696.

11. Vd Harishchandra Singh Kushvaha, Charak Samhita, reprints 2016, Chaukhamba Orientaliya Varanasi, Page No.690.

12. Prof. Jyotirmitra, Ashtanga sangraha, Reprint 2016, Chaukhamba Sanskrit Prakashan, Varanasi Page No. 328.

13. Vd Harishchandra Singh Kushvaha, Charak Samhita, reprints 2016, Chaukhamba Orientaliya Varanasi, Page No.689

14. Vd Harishchandra Singh Kushvaha, Charak Samhita, reprints 2016, Chaukhamba Orientaliya Varanasi, Page No.688

15. Vd Harishchandra Singh Kushvaha, Charak Samhita, reprints 2016, Chaukhamba Orientaliya Varanasi, Page No.691.

16. P. G. Athavale, Drushtartha Ashtangasangraha, reprint 2006, Govari Publishers Nagpur, Page No.161.

17. Kaustubh S. Chaudhari, Nishant R. Tiwari, Rakesh R. Tiwari, Rohan S. Sharma, Neurocognitive Effect of Nootropic Drug Brahmi (Bacopa monnieri) in Alzheimer's Disease, 12 May 2017, Annals of Neurosciences

\section{Source of Support: Nil \\ Conflict of Interest: None Declared}

How to cite this URL: Bhargav G. Tappe et al: Evaluation Of Smrutirhasa (Memory Loss) In Old Aged Individuals And Effect Of Bramhi Siddha Ghrita On Short Term Memory Loss. International Ayurvedic Medical Journal \{online\} 2020 \{cited August, 2020\} Available from: http://www.iamj.in/posts/images/upload/4078 4083.pdf 